\title{
A BOLOGNA-REFORM ÉS A NÉMETORSZÁGI PEDAGÓGUSKÉPZÉS
}

\section{ÓHIDY ANDREA}

\author{
a Münsteri Westfälische Wilhems-Egyetem Neveléstudományi Karának \\ tudományos munkatársa \\ andrea.ohidy@uni-muenster.de
}

\begin{abstract}
Az aktuális német oktatáspolitikai vita egyik központi kérdése a Bologna-reformcélok megvalósitása. A felsőoktatás szerkezeti átalakitása alapvető változást jelent a pedagógusképzés számára is. Az eddigi megvalósitást minden érintett - fóként a képzésben részt vevö diákok és tanárok-elhibázottnak tekintik és „,worst-practice-példaként“ emlegetik. A tanulmány a Bologna-reformcélok összeegyeztethetöségét vizsgálja a német pedagógusképzes hagyományaival, bemutatja az eddig bevezetett intézkedéseket és azok hatását, valamint a pedagógusképzés (további) professzionalizációjának lehetöségeit tárgyalja.
\end{abstract}

Az 1999-ben kezdeményezett Bologna-folyamat egy közös európai felsőoktatási terület létrehozására az első olyan európai szintű oktatáspolitikai kezdeményezés, amely jelenleg már a megvalósítási szakaszban tart. ${ }^{1}$ Ennek megfelelöen fontos helyet foglal el az érintett országok oktatáspolitikai vitájában, amely ellentmondásokkal teli; míg az Amerikai Egyesült Államok és Japán az európai felsőoktatási reformot haladó szellemű és konkurenciaképes reformnak értékelik ${ }^{2}$, az EU több tagállamában erősen vitatottak a Bologna-intézkedések. Különösen Németországban figyelhető meg széleskörü konszenzus a Bologna-célok megvalósításának hibáit illetően: A diákok országos tüntetések formájában adnak hangot nemtetszésüknek, az egyetemi dolgozók egyre gyakrabban beszélnek a „humboldti egyetemi hagyományok felszámolásáról”, a szakszervezet pedig „végállomás: Bologná”-t emleget. A növekvő politikai nyomásnak engedve a Kultuszminiszteri Konferencia (Kultusministerkonferenz) és a Felsőoktatási Rektorkonferencia (Hochschulrektorenkonferenz) a 2009-es év végén a „reform megreformálását" határozták el. Az európai oktatási miniszterek 2010. március 11. és 12-én - eredetileg zárókonfrenciaként tervezett - Bécsben és Budapesten megrendezett találkozója során meghir-

\footnotetext{
${ }^{1}$ A közös európai felsőoktatási terület megvalósítását eredetileg 2010-re tervezték.

22009 áprilisában indították el a „Tuning USA“ elnevezésű programot a Bologna-folyamat amerikai adaptálására (lásd Wiarda, 2009).
} 
dették a Bologna-reform második szakaszát, melynek feladata az eddigi megvalósítás hibáinak kiküszöbölése. ${ }^{1}$

E tanulmány központi kérdése az, hogy összeegyeztethetőek-e a Bologna-reformcélok a német pedagógusképzés hagyományaival. Először az eddig bevezetett oktatáspolitikai reformintézkedéseket mutatom be, azután az aktuális helyzetet vitatom meg a német pedagógusképzés (további) professzionalizációjának szemszögéből. A téma társadalompolitikai jelentőségét a Bologna-folyamat egész Európára kiterjedő igénye, tehát a közös európai felsőoktatási terület létrehozásának terve adja, a Bologna-folyamat második szakaszának kezdete pedig még megerősíti a téma aktualitását. Ezenkívül pedig elmondhatjuk, hogy az európai oktatáspolitikának egyik alapvető fontosságú kérdését tárgyaljuk: Amennyiben a fenti kérdésre adott válasz nemleges, ez azt jelenti, hogy az eddigi megvalósítás veszélyezteti az Európai Unió igyekezetét a tagállamok sokféleségének megtartására (Europäische Kommission, 2002).

Egy másik alapvető kérdés a szociális dimenzió figyelmen kívül hagyásához kapcsolódik; a müveltség, mint polgárjog, minden oktatáspolitikával foglalkozó EU-dokumentum központi célkitüzése (Europäischer Rat und Kommission, 2002). Továbbá, ahogy Dominic Orr kifejtette, a Bologna-reform Európán kívül márkajelzéssé vált, amely azt szimbolizálja, hogy „az európai felsőoktatás a szociális esélyegyenlőség jegyében valósul meg“, és hogy az oktatás nemcsak gazdasági tényezőként, hanem társadalompolitikai hajtóerőként is fontos (Brömme/Kloppisch, 2010). A „tanulás - demokráciára való nevelés - szabadság” triásza az európai pedagógia egyik alappillérének tekinthető (Óhidy, 2008, 19. o.). A szociális dimenzió figyelmen kívül hagyása ezt az alappillért ,rengeti meg”.

\section{A Bologna-reformfolyamat célkitüzései}

Az 1999-ben 29 európai ország oktatási minisztere által kezdeményezett Bolognafolyamat célja egy közös európai felsőoktatási tér (European Higher Education Area, EHEA) kialakítása, amelynek eredetileg 2010-ig le kellett volna játszódnia. A reform középpontjában az európai felsőoktatási rendszer nemzetközi szintü versenyképességének javítása áll. ${ }^{2}$ Bár a reformkezdeményezés az Európai Unió szervezetei nélkül indult, a Bologna-folyamat az ezredforduló óta fontos része az EU Lisszabon-stratégiájának, melynek célja, hogy az Unió a világ legversenyképesebb és legdinamikusabb tudásalapú társadalmává váljon (v. ö. Óhidy, 2009a). A következő táblázat a Bologna-nyilatkozatban megfogalmazott célkitüzéseket foglalja össze.

\footnotetext{
${ }^{1}$ A 2010 március 11-12-én Bécsben és Budapesten megtartott Bologna-konferencián a résztvevő 47 európai ország oktatási minisztere elismerte, hogy a reformtervek eddigi megvalósításába hibák csúsztak. A záró nyilatkozatban megígérték, hogy a kritikáknak a jövőben nagyobb jelentőséget fognak tulajdonítani. (Tagesspiegel, 2010). Németországban is beharangozták egy második ill. „,az eddigi megvalósítás hibáinak kiküszöbölésére irányuló szakasz" kezdetét (HRK, 2010).

${ }^{2}$ Egy részletes összefoglalóhoz lásd Wedekämper, 2007.
} 
1. táblázat: A Bologna-reformfolyamat célkitüzései (Bologna nyilatkozat, 1999)

\begin{tabular}{|l|}
\hline $\begin{array}{l}\text { Könnyen érthetö és összehasonlítható fokozatot adó képzési rendszer bevezetése } \\
\text { (oklevélmelléklet) }\end{array}$ \\
\hline $\begin{array}{l}\text { Két fö képzési szakaszon; egy három évig tartó alapképzésen (undergraduate) } \\
\text { és a magiszteri vagy mesterképzésen (graduate) alapuló rendszer bevezetése. Az első } \\
\text { szakasz után adott fokozat, mint megfelelö képesítés alkalmazható az európai } \\
\text { munkaeröpiacon. A második képzési szakasz magiszteri vagy doktori fokozathoz vezet. }\end{array}$ \\
\hline $\begin{array}{l}\text { Kreditpontrendszer - mint az ECTS - bevezetése a legszélesebb hallgatói mobilitás } \\
\text { elösegítésére. Legyen lehetöség a kreditpontok megszerzésére a felsőoktatáson kívüli, } \\
\text { pl. az élethosszig tartó tanulás keretében, feltéve, hogy azt a felsőoktatási intézmények is } \\
\text { elfogadják. }\end{array}$ \\
\hline $\begin{array}{l}\text { A mobilitás támogatása, különös tekintettel: } \\
-\quad \text { a hallgatók tanuláshoz és az ehhez kapcsolódó szolgáltatásokhoz való hozzájutására; } \\
\text { - a tanárok, kutatók és az adminisztratív dolgozók számára, az európai partnereknél } \\
\text { kutatással, oktatással és gyakorlattal eltöltött időszakban a vonatkozó } \\
\text { társadalombiztosítási jogok előítélet nélküli figyelembevételére. }\end{array}$ \\
\hline $\begin{array}{l}\text { A minőségbiztosítás területén az összehasonlítható kritériumokon és módszereken alapuló } \\
\text { európai együttmüködés kialakításának támogatása. }\end{array}$ \\
\hline $\begin{array}{l}\text { A felsőoktatás szükséges európai dimenzióinak támogatása, különösen a tantárgyfejlesz- } \\
\text { téssel, intézményközi kooperációval, mobilitási lehetőségekkel és a tanulmányokra, } \\
\text { a gyakorlati képzésre, és a kutatásra vonatkozó integrált programokkal. }\end{array}$
\end{tabular}

\section{A Bologna-reform németországi megvalósítása}

A német Bologna-reform a „mennyiségi siker - minőségi balsiker” paradoxonával fejezhető ki legjobban: „Németországban a Bologna-reform mennyiségi szempontból átütő siker“, állapítja meg Anna Lehmann. „A szövetségi oktatási minisztérium aktuális adatai alapján a képzési rendszer $80 \%$-a a Bachelor- és Master-rendszer keretében müködik, és minden ötödik végzős diák e képzettségek egyikét kapja kézhez" (Lehmann, 2010, 18. o.). A Bologna-reform németországi megvalósítását ugyanakkor kezdettől fogva egy alapvető ellentmondás jellemezte: annak ellenére, hogy a reformcélok általánosan elfogadottak, az azokhoz kapcsolódó konkrét oktatáspolitikai reformok, mint például a képzési szerkezet átalakítása, erősen vitatottak. Bár Németország a Bologna-folyamat egyik kezdeményezője (1. SorbonneErklärung, 1998), a reformcélok németországi megvalósítása sokszor ellentmond a célkitüzéseknek. Ingrid Sehbrock, a Német Szakszervezeti Szövetség nevelésoktatási ügyekért felelős alelnöke ezt a következőképpen fogalmazta meg: „Ma, 10 évvel Bologna után, a reformok eredménye kijózanító. Túlzsúfolt tantervek, a képzést abbahagyók megnövekedett száma, a külföldi tanulást megnehezítő körülmé- 
nyek határozzák meg a felsőoktatási intézmények mindennapjait“ (GEW Landesverband $N R W, 2009,2$. o.).

A Bologna-célkitüzések ezen ellentmondásos megvalósításának több oka is van, melyek közül ötöt szeretnék kiemelni:

1. Az egyik fó ok a Bologna-céloknak a csak a képzés szerkezeti változásaira koncentráló értelmezése. Baumann megállapítja, hogy Németországban a Bologna-reformot nem egy átfogó reformprogramként értelmezik, hanem a képzés szerkezetének a Bachelor és Master-képzésre való átalakítását értik alatta (lásd $D A A D, 2007,16$. o.). Andreas Keller ezért a „szerkezeti vita önállósodásáról“ beszél (Keller, 2009a, 149. o.).

2. Másodszor, a föderális döntési struktúra és az ebböl eredő hatalmi harcok a felelösek. A szupranacionális szinten történő döntéshozásban résztvevő aktorok, - mint például a nemzeti kormányok - szempontjából nem létezik demokratikus vagy legitimációs probléma, mert ők maguk is részei a döntési folyamatnak. A döntéshozásban részt nem vevő érdekcsoportosulások azonban, - mint például a tartományi szintủ oktatáspolitikai aktorok vagy maguk az egyetemek - ezeket az intézkedéseket felülről jövő elóirásokként, valamint hatáskörük csökkenéseként élik meg (Schemmann, 2007, 133. o.). Ez a probléma nehezíti a reformcélkitüzések megfelelő megvalósítását és - ahogy Günter Dohmen az élethosszig tartó tanulás paradigmájával kapcsolatban megfogalmazta - elősegíti azoknak a reformellenes erőknek az előretörését, amelyek saját pozíciójuk megőrzésének érdekében vagy választástaktikai okokból annak meghiúsulását igyekeznek elérni (Dohmen, 1996, 91. o.).

3. Harmadszor, a németországi pártpolitika is - a föderális döntési struktúrákkal és hatalmi harcokkal karöltve - döntő szerepet játszik a bolognai reformok problémás megvalósításában. Például Ulf Wuggering a felsőoktatási tandíj bevezetésének esetén keresztül bemutatta, hogyan hiúsították meg a konzervatív tartományi kormányok a baloldali szövetségi kormánynak a központi (szövetségi) döntési szint megerösítésére irányuló erőfeszítéseit az oktatáspolitikai döntésekben (Wuggenig, 2009).

4. Negyedszer, az amerikai modell szerepét kell kiemelnünk. Az Amerikai Egyesült Államok az európai döntéshozók számára egyidejüleg szolgál példaképként és ellenségképként is. Ez különösen igaz Németországgal kapcsolatban, mert az NSZK demokratikus és piacgazdasági fejlődése nagy mértékben az USÁ-nak köszönhető. A Szovjetúnió és a szocialista tábor összeomlása következtében az USA vezető szerepe ideológiailag (is) nagyon megerősödött. Ez is közrejátszik abban, hogy Németország a nemzetközileg elismert - és többek között az amerikai elitegyetemek által adaptált - egyetemi modelljét revíziónak veti alá. 
5. Ötödször, a Bologna-reformmal szembeni ellenállás egy kettős „címkehamisítás“ eredménye. Egyrészt az összeurópai szinten, ahol a minden tagállam által elismert célok, mint az átláthatóság és a mobilitás „cimkéje“ alatt teljesen más tartalmak kerülnek megvalósításra, például az oktatáspolitikai kérdések ökonomizációja. F. Schultheis a Bologna-reformot ezért „trójai falónak" titulálja (Schultheis, 2008, 191. o.). Németországban pedig „régóta esedékes reformok [...] kerülnek megvalósításra a 'Bologna' címszó alatt [...], melyeknek valójában semmi közük nincs a Bologna-célokhoz" (Sebastian in DAAD, 2007, 22. o.). Ezért az oktatási reformok nemzeti szintjén is „címkehamisításról“ beszélhetünk. Mi sem mutatja ezt jobban, minthogy a „Bologna“ címszó alatt bevezetett felsőoktatási reformok megvalósítása már a Bologna-nyilatkozat előtt megkezdődött: A Felsőoktatási kerettörvényt (Hochschulrahmengesetz (HRG)), amely a Bachelor és Master szakok bevezetésének jogi alapját alkotja - ezeket eredetileg csak kipróbálásra akarták bevezetni - már 1998-ban meghozták. „Ezért feltételezzük, hogy a Bologna-folyamat Németország számára [...] elsősorban az intranacionális (kiemelés tőlem - Ó. A.) változtatások megerösítésének és legitimációjának funkcióját tölti be“ (Wuggenig, 2009, 138. o.). A következő táblázat a Bologna-reform németországi megvalósításának különlegességeit mutatja be (Witte, 2006 és Wuggenig, 2008 alapján):

2. táblázat: A Bologna-reform németországi megvalósításának különlegességei

Az oktatáspolitikai döntéshozás a 16 szövetségi tartomány konszenzusa alapján történik, a Kultuszminiszteri Konferencia (KMK) keretében.

Az új, kétciklusú képzés jogi alapjai tartományok szerint különbözőek - az egyetlen hasonlóság, hogy minden Bachelor-képzésnek szakképzés-jellegünek kell lennie.

A Bachelor és a Master-képzés közötti átmenet Németországban sokkal nehezebb, mint más országokban.

Az új szakok akkreditálása nem állami engedélyezés, hanem magánkézben levő akkreditációs ügynökségek által történik.

Azáltal, hogy nemcsak az egyetemek, hanem a föiskolák is indíthatnak Master-szakokat, az egyetemek és a főiskolák egyenlősítésére kerül sor.

Az egyetemi tanterv modularizálása a felsőoktatási reformok keretében.

\section{A németországi Bologna-reform kritikája és a „megreformált reform”}

A fent bemutatott ellentmondások a felsőoktatási intézmények szintjén is megfigyelhetők: Míg az egyetemi tanárok a Bologna-folyamatot kezdettől fogva kritikusan fogadták, a diákok támogatták a célkitüzéseket. A megvalósítást azonban erősen kriti- 
zálták, ahogy azt a 2009 júniusában megtartott országos színtü diáktüntetés is mutatta. Azóta minden érdekelt egyetért abban, melyek a németországi Bologna-reform kritikus pontjai. Mielőtt ezeket összefoglalom, bemutatom - a teljesség igénye nélkül - a diákok és a tanárok által legtöbbször felsorolt problémákat és hátrányokat.

A diákok problémái:

- szociális szelekció (tandíj, a Master szak felvételének szabályozása),

- túlszabályozás (túlzsúfolt tanrendek, nincs lehetőség a képzés keretében egyéni érdeklődés szerint órákat hallgatni, nincs idő a tanulás melletti diákmunkára, hobbikra),

- stressz, burn-out ${ }^{1}$,

- az önálló gondolkodás nem fontos, ${ }^{2}$

- a nemzeti ${ }^{3}$ és nemzetközi mobilitás ${ }^{4}$ hiánya.

A diákok a Bologna-folyamat németországi megvalósítását összességében elhibázottnak tekintik, és úgy gondolják, hogy az egyes intézkedésekkel szemben a reformfolyamat átfogó célja, a közös európai felsőoktatási terület létrehozása a háttérbe szorult (freier zusammenschluss von studentInnenschaften, 2004).

A tanárok problémái:

- a kutatás és a tanítás szabadsága egyre fogy (elitegyetemek alapítása, föiskolai tanácsok létrehozatala, ökonomizáció és rosszul értelmezett effektivitáselv),

- magas munkaterhelés ${ }^{5}$,

- az egyetemi életet tudománytól távol álló elképzelések határozzák meg,

- mérhető eredmények felmutatásának kényszere - nincs idő a tartalmi munkára.

Ezért sok egyetemi dolgozó ,,a német egyetem és a humboldti egyetemi hagyományok végét" emlegeti. A Német Felsőoktatási Intézmények Egyesülete (Deutscher Hochschulverband) egy „Bologna-feketekönyvet“is kiadott (Scholz/Stein, 2009). Dietrich Lemke pedig kijelentette: „Bologna egyszer büszke lehetett arra,

\footnotetext{
${ }^{1}$ „A ránk nehezedő nyomás az egész képzést tönkreteszi [...], csak vizsgák, semmi önrendelkezés, éjszakai tanulások. A Bachelor- és Master-képzés újraszervezése nélkül ez így nem mehet tovább“ (Erziehung und Wissenschaft, 2009, 7-8. sz. 31. o.).

2 „Provokatívan azt mondhatnók, hogy (sok területen) a diákok uniformizálása folyik: Mindegyiküknek egyszerre kellene mozognia, egyidejüleg ugyanazokat a szemináriumokat hallgatni, ugyanazt tanulni, ugyanazokat a vizsgákat letenni, ezekért érdemjegyeket kapni, és a következő félévben mindez kezdődik előlröl“" (Tegeler, 2010, 139. o.).

${ }^{3}$ Gyakran ironikusan megjegyzik, hogy a mobilitás két EU-tagország között még mindig egyszerübb, mint két német egyetem között (lásd Egetenmeyer, 2007).

4 „Az egyetlen lehetőség egy ERASMUS-félév beiktatására a Bachelor- és a Master szakasz között van“ [...] „Közismert, hogy az ECTS-pontokat országonként nagyon különbözőképpen adják. Például Angliában és Németországban különböző számú kreditpontokat adnak ugyanazért a teljesítményért. Ezáltal az ECTS-pontrendszer lényege kerül veszélybe“ (Óhidy, 2009b, 726. o.).

5 „Az eddigi vitában az egyetemi dolgozók munkaterhelése mindeddig nem került megemlítésre“ (Bellenberg, 2009, 16. о.).
} 
hogy Európában megalapította az első egyetemet. Ez 1088-ban volt. Kár, hogy a Bologna név most az Európai Egyetem temetésének is szimbóluma lett!“ (Lemke, 2008, 308. o.).

A növekvő politikai nyomás hatására a Kultuszminiszteri Konferencia és a Felsőoktatási Rektorkonferencia a 2009-es év végén a „reform megreformálását“ határozták el. A következő táblázat ennek legfontosabb pontjait foglalja össze a 2009, 12. 10-i KMK-határozat alapján (KMK, 2009).

3. táblázat: A „megreformált reform“

\begin{tabular}{|l|}
\hline A képzés tanulhatóságának ${ }^{1}$ javítása, mobilitási lehetőségek kiépítése \\
\hline Egyéni tanulási folyamatok lehetővé tétele \\
\hline Széleskörü tudományos képzés biztosítása \\
\hline A Master-képzésbe való bekerülés leegyszerüsítése \\
\hline A képzési szerkezet átláthatóságának javítása \\
\hline A tanulhatóság ellenőrzése az akkreditáció során \\
\hline A képzés során elsajátított kompetenciák megnevezése („,oklevélmelléklet“) \\
\hline A vizsgák számának csökkentése \\
\hline A tanulmányi teljesítmények kölcsönös elismerésének javítása \\
\hline A munkaterhelés csökkentése \\
\hline
\end{tabular}

\section{A német pedagógusképzés a Bologna-reform előttt és után}

Az alábbiakban elöször is a német pedagógusképzés hagyományait, valamint az eddig bevezetett oktatáspolitikai reformintézkedéseket mutatom be és vitatom meg a (további) professzionalizáció szemszögéből. Mivel az oktatáspolitikai vita középpontjában a pedagógusképzés szerkezeti megváltoztatása áll, ennek a témának különös figyelmet szentelek.

A német pedagógusképzés a szövetségi tartományok hatáskörébe tartozik. Emiatt nincs egységes pedagógusképzési rendszer, de már a Bologna-reformok előtt is léteztek szerkezeti hasonlóságok, amelyek - valamennyi változtatással - máig érvényesek. A képzés kétciklusú: az első szakasz egy egyetemi képzés formájában elvégzendő elméleti képzésből áll és az ún. első államvizsgával (Erstes Staatsexamem) zárul. A képzés tartalmilag 2 (vagy 3 ) szakot és neveléstudományi tanulmányokat foglal magába, amelyek azonban a képzésnek csak kb. 5-20\%-át adják (Terhart, 2008, 88. o.). A második szakasz egy gyakorlati részből áll (Refendariat), ami két különbözö helyen folyik: a gyakorlóiskolában és a tanulmányi szeminári-

\footnotetext{
${ }^{1}$ A tanulhatóság javításának szükségessége itt szó szerint értendö: sok új szak nem végezhető el a tervezett idő alatt, azaz nem tanulható - a reformok ezt próbálják kijavitani.
} 
um keretében. Ez a szakasz az ún. második államvizsgával (Zweites Staatsexamen) fejeződik be. Létezik még egy harmadik szakasz is, melynek keretében a tanárok önállóan továbbképzik magukat - de ezen kötelezettség teljesítését nem ellenőrzik és annak elmaradását nem szankcionálják.

4. táblázat: A Bologna-reform előtti modell szerkezeti problémái

\begin{tabular}{|c|c|}
\hline Szakasz & Szerkezeti problémák \\
\hline $\begin{array}{l}\text { 1. szakasz: } \\
\text { egyetemi képzés }\end{array}$ & 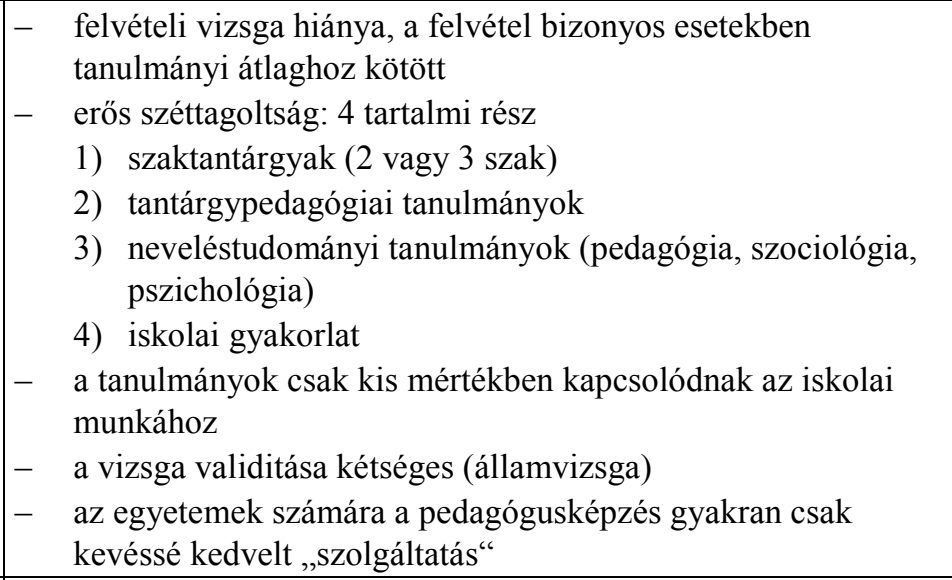 \\
\hline $\begin{array}{l}\text { 2. szakasz: } \\
\text { gyakornoki szakasz }\end{array}$ & $\begin{array}{ll}- & \text { semmilyen vagy nagyon kevés tartalmi összefüggés az első } \\
& \text { szakaszban tanultakkal } \\
- & \text { a gyakorlaton résztvevők tisztázatlan státusza (kezdő tanár / } \\
& \text { gyakornok) } \\
- & \text { a mentortanároktól való függés } \\
- & \text { a mentorok képzettségének és továbbképzésének kérdései } \\
& \text { tisztázatlanok } \\
- & \text { önálló tanulási lehetőségek alacsony mértéke } \\
- & \text { helyettesítések } \\
- & \text { magas pszichológiai megterhelés }\end{array}$ \\
\hline $\begin{array}{l}\text { 3. szakasz: } \\
\text { továbbképzés }\end{array}$ & $\begin{array}{ll}\text { - } & \text { bonyolult munkába állási feltételek } \\
\text { - } & \text { pályakezdési ,,sokk“ } \\
\text { - } & \text { a már meglévő iskolai hagyományok átvétele a tanításban, a } \\
& \text { továbbképzés nem hatásos } \\
\text { - } & \text { továbbképzés nem kötelező } \\
\text { - } & \text { nincs összefüggés a szakmai hozzáértés és a karrierlehetőségek } \\
& \text { közt }\end{array}$ \\
\hline
\end{tabular}


A német pedagógusképzés szerkezete az ún. klasszikus professziók (jog, orvostudomány, teológia) képzési szerkezetét vette át. Mivel a professzionalitástörténeti kutatás a tanári szakmát több okból is csak félprofesszionálisnak tekinti (lásd pl. Osterloh, 2002), a német pedagógusképzés kiemelkedő professzionalizációjáról beszélhetünk - ami ettől függetlenül erősen vitatott. A következő táblázat az Bologna-reform elötti modell szerkezeti problémáit mutatja be Terhart összefoglalása alapján (Terhart, 2008):

A német szövetségi tartományok oktatáspolitikája a Bologna-célokat különbözőképpen interpretálta és igyekezett megvalósítani a pedagógusképzésben, ezért a képzési szerkezet tartományonként nagyon eltérő képet mutat. Keller ezt „,színes rongyszőnyegnek" nevezi, mert az amúgy is heterogén összkép áttekintehtősége még nehezebbé vált (Keller, $2009^{\circ}$, 8. o.). Schaeper megállapítja, hogy: „A Bologna-folyamat, amely eredetileg a felsőoktatási rendszer egységesítését tüzte ki célul, a pedagógusképzésben a képzési struktúrák mérhetetlen sokféleségéhez vezetett" (Schaper, 2008. 34. o.). A következő táblázat az új képzési szerkezet bevezetésének állását mutatja Wuggenig összefoglalása alapján (Wuggenig, 2008, 137. o.).

5. táblázat: Az új képzési szerkezet bevezetésének állása

\begin{tabular}{|c|c|}
\hline Az új képzési szerkezet bevezetésének állása & Tartományok \\
\hline Az új képzési szerkezet már bevezetésre került. & $\begin{array}{l}\text { Saar-vidék } \\
\text { Szász-Anhalt }\end{array}$ \\
\hline $\begin{array}{l}\text { Az új képzési szerkezet csak egy meghatározott formában } \\
\text { (modelprojektként, csak meghatározott iskolatípusokra, } \\
\text { illetve föiskolai intézményekre vonatkozóan) került } \\
\text { bevezetésre. }\end{array}$ & $\begin{array}{l}\text { Baden-Württemberg } \\
\text { Bajorország } \\
\text { Hessen } \\
\text { Mecklenburg-Elő- } \\
\text { Pomeránia } \\
\text { Türingia }\end{array}$ \\
\hline Az új képzési szerkezet átfogó bevezetése folyamatban van. & $\begin{array}{l}\text { Hamburg } \\
\text { Észak-Rajna-Vesztfália } \\
\text { Rajnavidék-Pfalz } \\
\text { Schleswig-Holstein } \\
\end{array}$ \\
\hline $\begin{array}{l}\text { Az új képzési szerkezet átfogó fromában fog bevezetésre } \\
\text { kerülni. }\end{array}$ & $\begin{array}{l}\text { Berlin } \\
\text { Brandenburg } \\
\text { Bréma } \\
\text { Alsó-Szászország } \\
\text { Szászország }\end{array}$ \\
\hline
\end{tabular}


A következő jellemzők minden németországi tartomány pedagógusképzésére vonatkoznak: A képzés tantervének modularizálása, az ECTS-re (European Credit Transfer System) épülő kreditpontrendszer bevezetése (kivéve Mecklenburg-ElöPomerániában) ugyanúgy ide tartozik, mint az, hogy megtartották a képzés és a képesítés iskolatípusok alapján történő differenciáltságát (Bellenberg, 2009, 16. o.). A Kultuszminiszteri Konferencia a németországi Bachelor- és a Master-képzés együttes terjedelmét 300 ECTS-ban határozta meg, amelyeket rendszerint egy ötéves képzés során lehet megszerezni $(K M K, 2003)$. A pedagógusképzésben bevezették az ún. „kis Master"-t, („,kleiner Master"), amelynek során a hallgatók 240 ECTS szereznek egy négyéves képzés során. Ezenkívül lehetővé tették, hogy a gyakornoki szakasz meghatározott részeit a Master-képzés részeként lehet elszámolni. Az egyetemeken kiépítik a Tanárképző Központokat (Zentrum für Lehrerbildung). Már a fenti felsorolás is világosan mutatja, hogy a Bologna-reform Németországban a pedagógusképzés első és második szakaszát érinti. A vita elsősorban az első szakaszra koncentrálódik. Sajnos a tanárok továbbképzésének kérdése továbbra sem vita tárgya pedig ez fontos szerepet játszhatna a tanári szakma (további) professzionalizációja szempontjából. A következő táblázat a bevezetett intézkedéseket, illetve azok problémáit foglalja össze, különös tekintettel a professzionalizációs dimenzióra.

6. táblázat: Az újonnan bevezetett intézkedések és azok problémái, különös tekintettel a pedagógusképzés professzionalizációs dimenziójára

\begin{tabular}{|l|l|l|}
\hline \multicolumn{1}{|c|}{ Bevezetett intézkedés } & \multicolumn{1}{|c|}{ Probléma } & \multicolumn{1}{c|}{$\begin{array}{c}\text { A professzionalizáció } \\
\text { dimenziója }\end{array}$} \\
\hline $\begin{array}{l}\text { A képzési szerkezet } \\
\text { sokfélesége }\end{array}$ & $\begin{array}{l}\text { Belföldi és külföldi mobilitás } \\
\text { nehézségei }\end{array}$ & Horizonttágítás hiánya \\
\hline $\begin{array}{l}\text { A képzés és a képesítés } \\
\text { iskolatípusok alapján } \\
\text { való } \\
\text { differenciáltságának } \\
\text { megtartása }\end{array}$ & $\begin{array}{l}\text { A különféle iskolaformák } \\
\text { különbözö professzionalitási } \\
\text { szintje a ,kis gyerek - rövid } \\
\text { képzés, nagy gyerek - hosszú } \\
\text { képzés“ elve alapján (Keller } \\
\text { 2009c, 32) }\end{array}$ & $\begin{array}{l}\text { A tanári szakma belső } \\
\text { differenciáltságának } \\
\text { megerösítése }\end{array}$ \\
\hline $\begin{array}{l}\text { Az ún. ,kis Master“ } \\
\text { bevezetése }\end{array}$ & $\begin{array}{l}\text { Az általános iskolai } \\
\text { tanítóképzés lefokozása }\end{array}$ & $\begin{array}{l}\text { Az általános iskolai tanítói } \\
\text { szakma lefokozása }\end{array}$ \\
\hline $\begin{array}{l}\text { Gyakornoki szakasz } \\
\text { mint a Master-képzés } \\
\text { része }\end{array}$ & $\begin{array}{l}\text { Gyakran hosszú várakozási idő } \\
\text { a gyakornoki szakasz előttt }\end{array}$ & $\begin{array}{l}\text { Lezáratlan képzés } \\
\text { a gyakornoki szakasz végéig }\end{array}$ \\
\hline $\begin{array}{l}\text { A Bachelor, mint } \\
\text { szakmai képzés }\end{array}$ & $\begin{array}{l}\text { A tanári pályához legalább egy } \\
\text { Master-szintü végzettség } \\
\text { szükséges }\end{array}$ & $\begin{array}{l}\text { A képzés tudományos része } \\
\text { nem kielégítő }\end{array}$ \\
\hline \multicolumn{2}{|l}{} \\
\hline
\end{tabular}




\begin{tabular}{|l|l|l|}
\hline \multicolumn{1}{|c|}{ Bevezetett intézkedés } & \multicolumn{1}{|c|}{ Probléma } & \multicolumn{1}{c|}{$\begin{array}{c}\text { A professzionalizáció } \\
\text { dimenziója }\end{array}$} \\
\hline $\begin{array}{l}\text { A Master-képzésbe való } \\
\text { bejutás behatárolása }\end{array}$ & $\begin{array}{l}\text { Zsákutcás képzés, a leendő } \\
\text { tanárok számára a Bachelor- } \\
\text { szintü végzettség nem elég a } \\
\text { pályán való elhelyezkedéshez }\end{array}$ & $\begin{array}{l}\text { Meghiúsulnak az egyéni } \\
\text { fejlesztés és a másság } \\
\text { kezelésének célkitüzései }\end{array}$ \\
\hline $\begin{array}{l}\text { (Rosszul értelmezett) } \\
\text { modularizáció }\end{array}$ & $\begin{array}{l}\text { „elöregyártott, gyakran } \\
\text { nehezen megemészthető } \\
\text { tanulási falatok“ (l. Tegeler } \\
\text { 2010, 139. o.) }\end{array}$ & Iskolásítás \\
\hline $\begin{array}{l}\text { Képzési tartalmak } \\
\text { túlterhelése }\end{array}$ & $\begin{array}{l}\text { Diákok túlterhelése, egyéni } \\
\text { érdeklödés alapján való tanulás } \\
\text { nehézségei }\end{array}$ & $\begin{array}{l}\text { Stressz, félelem, időhiány: } \\
\text { a személyiségfejlődés } \\
\text { problémái }\end{array}$ \\
\hline $\begin{array}{l}\text { Túl sok vizsga a képzés } \\
\text { folyamán }\end{array}$ & Diákok és tanárok túlterhelése & $\begin{array}{l}\text { „Tanulási bulimia“ önálló } \\
\text { gondolkodás és kutatás helyett }\end{array}$ \\
\hline
\end{tabular}

A németországi pedagógusképzés reformját a Bologna-folyamat keretében Andreas Keller „worst-practice-példának“ nevezi (Keller, 2009a, 8. o.). A reformcélkitüzések eddigi megvalósítása kétségkívúl sok kivánnivalót hagy maga után. Véleményem szerint ennek ellenére sem szabad a Bologna-folyamatban rejlő esélyeket és megoldási lehetőségeket figyelmen kívül hagyni. Az alábbiakban ezért azokat intézkedéseket sorolom fel, amelyek egyértelmủen pozitív hatással voltak a német pedagógusképzésre.

1. A pedagógusképzés jelentőségének megnövekedése: Ewald Terhart a pedagógusképzés általános jelentőségnövekedését konstaltálja: „Majdnem mindenhol saját Tanárképző Központokat hoztak létre, amelyek a pedagógusképzés szervezeti és tartalmi érdekeit az egyetemen belül és kivül egyaránt képviselik. Az egyetemi tanulmányok neveléstudományi része tartalmilag nagyobb mértékben kapcsolódik az iskolai munkához mint annakelőtte, a tantárgypedagógiai kutatások fellendültek." (Terhart, 2010, 7. o.). Ezenkívül, egyre több empirikus kutatás folyik a pedagógusképzés folyamatáról és hatásáról.

2. Jobb átláthatóság és nemzeti norma meghatározása a pedagógusképzés mindhárom pillére; azaz a neveléstudomány, a szaktudomány, és a tantárgypedagógia számára. „Világossá vált, mi az, amit a leendő pedagógusoknak a képzés befejezésekor tudniuk kell, mind a választott szak, mind a pedagógiai képességek tekintetében“ (Terhart, 2010, 5. o.). Ezáltal a leendő pedagógusok nemzeti és nemzetközi mobilitása is egyszerübbé válhat.

3. Az első és a második szakasz közötti együttmüködés kialakitása, vagyis a tanárképző felsőoktatási intézmények és a tanulmányi szemináriumok kö- 
zötti kooperáció megerősítése. Ennek során pozitív szinergetikus effektusok várhatók, mivel az eddigi gyakorlat során a pedagógusképzés első és második szakaszára nagyon eltérő szakmai szocializáció volt jellemző. Az elméleti és gyakorlati képzés szorosabb összekapcsolása mind neveléstudományi, mind professzióelméleti szempontból kívánatos. A pedagógusképzés decentralizált felépítése azonban - Keller ezt „,szervezett felelőtlenségnek" nevezi (Keller, 2009a, 10. o.) - továbbra is megmaradt.

4. Több gyakorlat az első szakaszban: ez a kritérium nemcsak a pedagógusképzésben résztvevők kívánsága, hanem törvényben meghatározott kötelezettség is (lásd Óhidy, Terhart, Zsolnai, 2008 harmadik fejezetét). Pozitív hatás, véleményem szerint, két területen várható: Egyrészt a pályaválasztást szükség esetén hamarabb lehet revidiálni mint korábban. Másrészt, a kezdő pedagógusok sokat emlegetett pályakezdési „sokkja” megelőzhetővé, illetve enyhíthetővé válik. Problémás lehet viszont, ha a tanítási gyakorlatok a gyakorló iskolákban tanító pedagógusok pedagógiai megoldásainak reflexió nélküli átvételére és begyakorlására szorítkozik.

5. A képzés folyamán leteendö vizsgákat a diákok jobb megoldásnak tartják mint a korábbi egyetlen, a képzés végén leteendő vizsgamodellt (Tegeler, 2010,138 . o.). Kritikus pont azonban a leteendő vizsgák mennyisége.

2010 márciusában nemcsak az európai, hanem a német oktatáspolitika aktorai is a Bologna-folyamat új szakaszát harangozták be. Margret Wintermantel, a Felsőoktatási Rektorkonferencia elnöke a következőket nyilatkozta ezzel kapcsolatban: "Németországban igyekszünk egy kooperációs kultúrát kialakítani a diákok és a tanárok közremüködésével. Tudjuk, hogy sok felsőoktatási intézmény példamutató új utakon jár. Új kommunikációs modelleket próbálnak ki, a képzés kialakítása során egyre inkább figyelembe veszik a diákok véleményét, és az intézmények minden tagja azon dolgozik, hogy az új képzések számára megbízható és egyidejüleg rugalmas szerkezetet alakítson ki” (HRK, 2010).

\section{Szubjektív összegzés: A német pedagógusképzés (további) professzionalizációjának lehetőségei és problémái}

A Bologna-reformfolyamat németországi megvalósításának mérlege összességében negatív. Viszont fontos pozitívum, hogy mára létrejött egy egész országot átfogó konszenzus arról, hogy a közös európai felsőoktatási tér kialakítása szükséges és fontos cél, ami a jövőben jobb megvalósítást érdemel. A problémákat tehát meghatároztuk, és ez az első lépést jelentheti a megoldásukhoz. A jövőbeni rendelkezések keretét véleményem szerint a következő két idézettel tudjuk megjelölni: „A Bologna-reformfolyamatban rejlő óriási lehetőségeket Németországban nem használtuk ki“ (Keller, 2009b, 8. o.) és „A Bologna-reform előtti idők nosztalgikus dicsőítésére nincs semmi okunk" (Weibler in Scholz/Stein, 2009, 86. o.). A Bologna-reform- 
folyamatnak a 2010 márciusában az európai oktatáspolitika szintjén beharangozott második szakaszát (nemcsak) Németországban arra kellene használnunk, hogy az eddigi hibás döntéseket átgondoljuk, tanuljunk a hibáinkból, valamint hogy a felsőoktatási rendszer szerkezeti átalakítását annak minőségi megjavítására használjuk. Ennek során nem szabadna sem az évszázadok óta bevált humboldti egyetemi ideált könnyelmúen feladni, sem pedig a - sok szempontból fontos és szükséges reformok kínálta jobbítási lehetőségeket kihasználatlanul hagyni és a „régi szép idők" szentimentalizmusába menekülni.

Véleményem szerint a legnagyobb probléma a reform hiányzó szociális dimenziója $^{1}$ - ezt lassan az oktatáspolitika minden szintjén felismerik és elismerik (legalábbis a politikai proklamációk szintjén). A pedagógusképzés esetében ez a tendencia különösen nagy problémákkal jár, mert ezáltal az iskolai rendszer szelekciós funkciója megerősödik. Ezzel kapcsolatban két aspektust szeretnék kiemelni, amelyek az egész oktatási rendszert átfogó negatív hatást a legszemléletesebben mutatják:

Először is, a pedagógusképzés szerkezetét továbbra is az erősen szelektív iskolarendszer határozza meg. Ezáltal a német oktatási rendszer egészének szelektivitása - amely köztudottan nem a tanulók tehetsége vagy teljesítménye, hanem szociális származása alapján működik - még megerősödik: „Az iskolarendszer tagolása szállítja a 'hardware-t', a pedagógusképzés hierarchikusan kialakított szerkezete pedig a 'software-t', - aminek az az eredménye, hogy a politikai beszédekben gyakran hangoztatott oktatáspolitikai cél, a migráns és hátrányos helyzetű családokból származó gyerekek és fiatalok szociális és kulturális integrációja szisztematikusan meghiúsul" (Keller, 2009c, 32. o.).

Másodszor pedig különösen súlyos problémának tartom a tandíj újrabevezetését a felsőoktatásban, mert ezáltal egyrészt a hátrányos helyzetben lévők társadalmi felemelkedésének lehetősége erősen csökken, másrészt mert a leendő tanárok szociális származás alapján történő szelektálásához vezet. Ezáltal a tanárok és diákok közti társadalmi szakadék (még jobban) megnő: a tanárok, akik középosztálybeli polgári családokban nevelkedtek fel, nem értik és sokszor nem is látják a hátrányos helyzetủ diákok problémáit. Nem értik például, mekkora problémát okoz, ha a tanulóknak matematika házi feladatként a családi autót kellene lemérniük ami nincs. Ezek a gyerekek nem tudják elvégezni a házi feladatot, de sokszor szégyellik megmondani az okát. A tanár pedig a hiányzó leckét, mint hiányzó teljesítményt értékeli. Ezáltal még inkább felerősödik a német iskolák (amúgy is nagyon erős) szociális szelekciója. A tanári professzionalizáció legfontosabb céljainak megvalósítása; a minden gyereknek megadandó egyéni fejlesztés és a mássággal

\footnotetext{
${ }^{1}$ Wuggenig a Bologna-reformfolyamatot egy „rejtett elitképzésről egy nyílt elit-képzésre való áttérésként“ értékeli (Wuggenig, 2008, 154. o.). Ahogy Soulié megfogalmazta: „Amíg a föiskolai képzés egy társadalmi osztály privilégiuma volt, ingyenes volt. Most, mikor minden korosztály érintett, és a rendelkezésre álló pénzforrások is jobbak, gazdasági és üzemgazdasági logika kerül a középpontba“ (Soulié in Schultheis/Cusin/Roca i Escoda, 2008, 88. o.).
} 
való bánni tudás kompetenciáinak kialakítása $(L A B G N R W, 2009,1$. o.) pedig lehetetlenné válik. Ahogy Gabriele Bellenberg megállapította: „a szerkezeti reformban a leendö tanárok professzionalizációja másodrangú szerepet játszik“ (Bellenberg, 2009, 15. о.).

Ezeket a problémákat mind a nemzeti, mind az európai oktatáspolitikai vitában többször felvetették és megnevezték, mára pedig általánosan elismerték. Ez a tény ad okot némi reményre, hogy az eddigi megvalósítás hibáinak kiküszöbölésével kapcsolatos igéretek nem maradnak meg a politikai proklamáció szintjén, és a célként kitüzött közös európai felsőoktatási tér nemcsak politikai jelszó marad, és nem válik a gazdasági érdekek legitimációs eszközévé sem. Ez különösen fontos lenne, mert a Bologna-reformcélok megvalósításához nemcsak egy „Német Oktatási Köztársaságra“ („Bildungsrepublik Deutschland”) van szükségünk - ahogy Angela Merkel szövetségi kancellár meghirdette -, hanem egy „Európai Oktatási Unióra” („Europäische Bildungsunion“) (Óhidy, 2009a, 293. o.) is.

\section{Irodalom}

Bellenberg, G. (2009): Bachelor- und Masterstudiengänge in der LehrerInnenbildung im Jahr 2008. Ein Vergleich der Ausbildungskonzepte in den Bundesländern. In: GEW: Endstation Bologna? Die Reformdebatte zur LehrerInnenbildung in den Ländern, im Bund und in Europa. GEW, Frankfurt, 5-11.

Bologna-Erklärung (1999): Der europäische Hochschulraum. Gemeinsame Erklärung der Europäischen Bildungsminister. 19. Juni 1999, Bologna. http://www.bmbf.de/pub/bologna_deu.pdf [Letöltve: 2010. 02. 25.].

Brömme, T., Kloppisch, K. H.: (2010): Alice, der Spiegel und die Studenten. BolognaKonferenz in Budapest und Wien.

http://www.neues-deutschland.de/artikel/167049.alice-der-spiegel-und-diestudenten.html. [Letöltve: 2010. 03. 15.].

DAAD (2007): Bologna in Deutschland. Erfahrungen und Einsichten der deutschen Bologna-Promoter. DAAD, Bonn.

Dohmen, G. (1996): Das lebenslange Lernen. Leitlinien einer modernen Bildungspolitik. Ministerium für Bildung, Wissenschaft, Forschung und Technologie, Bonn.

Egetenmeyer, R. (2007): Der „European Master in Adult Education“. Transnationale Studiengänge als Frucht des Bologna-Prozesse DIE, 3. sz. 35-38.

Europäische Kommission (2002/a): Unterschiedliche Systeme, gemeinsame Ziele für 2010. Arbeitsprogramm zur Umsetzung der Ziele der Systeme der allgemeinen und beruflichen Bildung. Amt für amtliche Veröffentlichungen der Europäischen Gemeinschaft. Brüssel.

Europäischer Rat und Kommission (2002): Lebenslanges Lernen: Bald Wirklichkeit für alle. Amt für amtliche Veröffentlichungen der Europäischen Gemeinschaften, Luxemburg.

freier zusammenschluss von studentInnenschaften (fzs) (2004): Für eine qualitative Studienreform, Beschluss der 25. Mitgliederversammlung in Passau, Mai 2004. 
GEW Landesverband NRW (2009): Bologna nachbessern! Zehn Jahre Studienstrukturreform. GEW, Essen.

Hochschulrektorenkonferenz (HRK) (2010): Pressemitteilung vom 15. 3. 2010.: HRK-Präsidentin nach der Konferenz der europäischen Wissenschaftsminister: Bologna-Reform 2010 - Aufbruch statt Abschlus http://www.verbaende.com/Newphp4?m=67813 [Letöltve: 2010. 03. 15.].

Keller, A. (2009a): Endstation Bologna? Für einen Kurswechsel in der Reform der LehrerInnenbildung. In: GEW: Endstation Bologna? Die Reformdebatte zur LehrerInnenbildung in den Ländern, im Bund und in Europa. GEW, Frankfurt, 5-11.

Keller, A. (2009b): Bologna 2.0 - Zeit für einen Kurswechsel. In: GEW Landesverband NRW (2009): Bologna nachbessern! Zehn Jahre Studienstrukturreform. GEW, Essen, 7-11.

Keller, A. (2009c): Vom Arbeitsplatz Schule weit entfernt. Selektives Schulsystem prägt die Lehrerausbildung. Erziehung und Wissenschaft, 11. sz. 32.

Kultusministerkonferenz (KMK) (2009): Meldung. Ergebnisse der 328. Plenarsitzung der Kultusministerkonferenz am 10. Dezember 2009. http://www.kmk.org/presse-undaktuelles/meldung/ergebnisse-der-3... [Letöltve: 2010. 01. 12.].

Kultusministerkonferenz (KMK) (2003): Ländergemeinsame Strukturvorgaben für die Akkreditierung von Bachelor- und Masterstudiengängen. KMK.

Lehmann, A. (2010): Minister bejubeln Bologna-Baustelle. Die Tageszeitung, 3. sz. 18.

Lehrerausbildungsgesetz (LABG) NRW (2009): Gesetz über die Ausbildung für Lehrämter an öffentlichen Schulen. Lehrerausbildungsgesetz, LABG, vom 12. 5. 2009.

Lemke, D. (2008): Bologna - az európai egyetem kezdete és vége. In: Óhidy, A./Terhart, E./ Zsolnai, J. (szerk.): Tanárkép és tanárképzés. A tanárképzés perspektivái Németországban és Magyarországon. Pannon Egyetem BTK Neveléstudományi Intézet Pedagógiai Oktató- és Kutatóközpont, Pápa, 292-311.

Óhidy, A. (2008): Lifelong learning. Interpretations of an Education Policy in Europe. VS Verlag für Sozialwissenschaften, Wiesbaden.

Óhidy, A. (2009a): Lebenslanges Lernen und die europäische Bildungspolitik. Adaptation des Lifelong Learning-Konzepts der Europäischen Union in Deutschland und Ungarn. VS Verlag für Sozialwissenschaften, Wiesbaden.

Óhidy, A. (2009b): Der Bologna-Prozess und die ERASMUS-Studentenmobilität in Deutschland - Anmerkungen zur europäischen und deutschen Hochschulpolitik. Pädagogische Rundschau, 6. sz. 719-731.

Óhidy, A., Terhart, E., Zsolnai, J. (szerk., 2008): Tanárkép és tanárképzés. A tanárképzés perspektivái Németországban és Magyarországon. Pannon Egyetem BTK Neveléstudományi Intézet Pedagógiai Oktató- és Kutatóközpont, Pápa.

Osterloh, J. (2002): Was heißt ,pädagogische Professionalität“"? Überlegungen zum Grundverständnis pädagogischer Berufe. Pädagogische Rundschau, 5. sz., 391-399.

Schaeper, K. (2008): Lehrerbildung nach Bologna. In: Lütgert, W. - Gröschner, A. - Kleinespel, K.: Die Zukunft der Lehrerbildung. Entwicklungslinien, Rahmenbedingungen, Grundlagen. Weinheim u. a., Beltz, 27-36. 
Schemmann, M. (2007): Internationale Weiterbildungspolitik und Globalisierung. Orientierungen und Aktivitäten von OECD, EU, UNESCO und Weltbank. Deutsches Institut für Erwachsenenbildung, Bielefeld.

Scholz, Ch./Stein, V. (Hrsg.) (2009): Bologna-Schwarzbuch. Deutscher Hochschulverband, Bonn.

Schultheis, F./Cousin, P.-F./Roca i Escodda, M. (Hrsg., 2008): Humboldts Albtraum. Der Bologna-Prozess und seine Folgen. UVK, Konstanz.

Schrittesser, I. (2009): University goes Bologna - zwischen Anspruch und Wirklichkeit. Eine Einführung. In: Schrittesser: University goes Bologna. Trends in der Hochschullehre. Entwicklungen, Herausforderungen, Erfahrungen. Facultas, Wien, 7-29.

Schultheis, F. (2008): Ein Resümee: Welche Universität für welches Europa? In: Schultheis, F. - Cousin, P. - F. Roca i Escodda, M. (Hrsg.): Humboldts Albtraum. Der Bologna-Prozess und seine Folgen. UVK, Konstanz.

Schützenmeister, J. (2005): Synopse der Lehrerausbildung europäischer Staaten. In: Schulz, D. - Kruze, A. - Lippke, W. (Hrsg.): Lehrerbildung in Europa - Lehrerbildung für Europa. Universitätsverlag, Leipzig, 77-122.

Sorbonne-Erklärung (1998): Gemeinsame Erklärung zur Harmonisierung der Architektur der europäischen Hochschulbildung. Sorbonne: Pari www.bologna-berlin2003.de/pdf/ Sorbonne_declaration.pdf [Letöltve: 2009. 07. 08.].

Tagesspiegel (2010): ,, Bologna mehr Schwung geben “. http://www.tagesspiegel.de/magazin /wissen/art304,3056916 [Letöltve: 2010. 03. 15.].

Tegeler, A.: Leistungsbewertungen, Prüfungen, Verschulung. Ein Beitrag aus studentischer Sicht. In: Deutsche Gesellschaft für Erziehungswissenschaft (DGfE) (2010): Erziehungswissenschaft. Heft 40, Jg. 21. Opladen: Barbara Budrich, 135-145.

Terhart, E. (2008): A tanárképzés szerkezeti problémái Németországban. In: Óhidy, A. Terhart, E. - Zsolnai, J. (szerk.): Tanárkép és tanárképzés. A tanárképzés perspektívái Németországban és Magyarországon. Pannon Egyetem BTK Neveléstudományi Intézet Pedagógiai Oktató- és Kutatóközpont, Pápa, 87-107.

Terhart, E. (2010): Der Bildung neue Formen geben - Ein Rückblick auf zehn Jahre Lehrerbildungsreform. Bildung und Erziehung, 1. sz. 4-9.

Wedekämper, K. (2007): Schaffung eines europäischen Hochschulraume Die gemeinsame Erklärung der europäischen Bildungsminister von Bologna und ihre Auswirkungen. In: Óhidy, A./Terhart, E./Zsolnai, J.: Lehrerbild und Lehrerbildung. Praxis und Perspektiven der Lehrerausbildung in Deutschland und Ungarn. VS Verlag, Wiesbaden, 249-267.

Wiarda, J.-M. (2009): Die Bologna-Kopie. Die Zeit, 16. sz. 65.

Witte, J. (2006): Die deutsche Umsetzung des Bologna-Prozesse. Aus Politik und Zeitgeschichte (APuZ), 48. sz. 21-27.

Wuggenig, U. (2008): Eine Transformation des universitären Feldes: Der Bologna-Prozess in Deutschland und seine Vorgeschichte. In: Schultheis, F./Cousin, P.-F./Roca i Escoda, M. (Hrsg.): Humboldts Albtraum. Der Bologna-Prozess und seine Folgen. UVK, Konstanz. 